\begin{tabular}{|l|l|}
\hline $\begin{array}{l}\text { Postprint } \\
\text { Version }\end{array}$ & 1.0 \\
\hline Journal website & $\underline{\text { http://linkinghub.elsevier.com/retrieve/pii/S0168851099000159 }}$ \\
\hline Pubmed link & $\underline{\text { http://www.ncbi.nlm.nih.gov/pubmed/10538289 }}$ \\
\hline DOI & \\
\hline
\end{tabular}

This is a NIVEL certified Post Print, more info at http://www.nivel.eu

\title{
National health interview surveys in Europe: an Overview
}

\author{
CHRISTIANNE L.H. HUPKENS ${ }^{\mathrm{A}, *}$, JAAP VAN DEN BERG ${ }^{\mathrm{B}}$, JOUKE VAN DER ZEE ${ }^{\mathrm{C}}$
}

a Department of Medical Sociology, Maastricht University, PO Box 616, 6200 MD Maastricht, The Netherlands

b Department of Sociocultural Household Surveys, Statistics Netherlands, PO Box 4481, 6401 CZ Heerlen, The Netherlands

c Department of Medical Sociology, Maastricht University and NIVEL, PO Box 1568,

3500 BN Utrecht, The Netherlands

\section{Abstract}

In order to study the value of national health interview surveys for national and international research and policy activities, this paper examines the existence and content of recent and future health interview surveys in the 15 member states of the European Union (EU), Norway, Iceland and Switzerland. National health interview surveys are performed in most countries, but not in Greece (only regional surveys), Luxembourg, Ireland and Iceland (only multi-purpose surveys). The health interview surveys in the other 14 countries provide regular data on the main health topics. Of the 14 health topics that are examined in this inventory seven are measured in all countries. Questions on health status (e.g. self-assessed health, long-term physical disability, and height and weight) and medical consumption (e.g. consultations with the general practitioner, GP) are often included. Lifestyle topics are less often included, except smoking habits, information about which is sought in all countries. Topics like diet and drugs:narcotics are more often included in special surveys than in general health interview surveys. Despite differences in the content, frequency and methodology of national health interview surveys in different countries, these surveys are a valuable source of information on the health of Europeans.

\section{INTRODUCTION}

The requirements of three influential organisations (WHO, OECD and the $\mathrm{EU}^{1}$ ) give an extra impetus for national governments of European countries to produce reliable and comparable health statistics. These statistics encompass the health status of the population (life-expectancy, morbidity and mortality), the supply and utilisation of health services, and health care costs and financing. More specifically, the WHO wants to monitor the success or 
failure of its 'Health for All for the Year 2000' programme, in which governments committed themselves to reduce health hazards and to improve the health of their populations considerably over a period of almost 25 years (1977-2000) [1]. The OECD collects and publishes for its member states ${ }^{2}$ a broad set of health and health care indicators and has put considerable efforts into improving the completeness and comparability of its indicators. The set serves two purposes: (1) as a monitoring instrument of this section of predominantly public spending, and (2) as a basis for comparative policy research and benchmarking. New developments will be the establishment of a set of generic health indicators on the one hand and of intervention sensitive indicators on the other.

With respect to efforts at the level of the EU, the Maastricht Treaty [2] and the Amsterdam Treaty [3] give a boost to community actions on public health. In their respective Articles 129 and 152 these treaties mentioned health information and education as key areas for community action. In order to fulfil this task the European Council and the European Parliament, on a proposal of the European Community (EC), adopted a programme of Community action on health monitoring 1997-2001 [4].

The WHO, the OECD and the EU use health data that are derived from health interview surveys and statistical records. The present paper focuses on health interview surveys: it examines whether surveys are a valuable source of national health indicators. More specifically, the paper explores which European countries have national health interview surveys, and whether these surveys cover the main topics that are being monitored. This paper is based on a study carried out for the EC on the existence and content of recent and future health interview surveys (conducted between 1994 and 2000) in the 15 EU member states and three neighbouring countries.

In addition, the results of this inventory are compared with the results of a WHO-initiated inventory on national health surveys in the period 1980-1990, performed by Evers [5]. The aim of that study was to establish if and how the 33 Health for All indicators were included in national surveys in 26 countries. There appeared to be large variations in the coverage of Health for All indicators varying from the inclusion of many indicators in one or more surveys (e.g. Italy, The Netherlands and the UK) to the inclusion of just a few indicators (e.g. Turkey, Ireland and Germany). Generally, indicators related to health status were included most often, followed by indicators on healthy lifestyles. Self-assessed health status, smoking habits, long-term disability, activities of daily living, long-term incapacity for work and the consumption of alcohol were measured in at least 20 countries.

Indicators on healthy environment (like access to drinking water) and on appropriate care (e.g. access to family planning) were covered least often. Evers [5] concluded that for some countries and for some indicators insufficient information is available to monitor progress.

Before we describe the method and results of our study, we dwell upon the pros and cons of health interview surveys as a source of national health indicators.

\subsection{Pros and cons of health interview surveys}

Health interview surveys are especially relevant for health indicators that cannot be collected by means of statistical records, like indicators on health status (e.g. the prevalence of chronic conditions, and self-assessed health as a measure for people's well-being), lifestyles (like smoking habits and alcohol consumption) and medical consumption (e.g. the use of medicines). Also modern health indicators like health expectancies and disabilityadjusted life years (DALYs) can only be calculated with help of survey data. An advantage of health survey data over statistical records is that they allow associations between different health variables to be studied, e.g.

between smoking habits and self-assessed health [6]. Moreover, health survey data can be used to analyse health variables according to a larger set of background variables like marital status, occupation and education than the age-sex divisions in the official health statistics [1]. Thus, health interview surveys are useful to detect high-risk groups. 
A possible disadvantage of survey data is that they rely on the respondents' judgements. This may affect, for example, the validity of prevalence rates of certain diseases. Generally, for many survey data the validity is not determined. Moreover, health surveys do not offer the opportunity to study causal relationships between lifestyles and health, as the information collected is generally cross-sectional.

Finally, the possibility to generalise data of national health interview surveys to the population at large is restricted if the non-response rates are high. Despite these limitations, national health survey data are considered to be useful for national and international research activities and policies $[7,8]$.

\subsection{Research questions}

The present paper is based on an inventory of health surveys in the 15 member states of the EU, Norway, Iceland and Switzerland in 1996, that was initiated by the Statistical Office of the European Communities (Eurostat). The inventory addressed the existence, content and comparability of national health interview surveys in the period 1994-2000. The Eurostat Task Force on Health and Healthrelated Survey Data has discussed each stage of this inventory. The final report on the inventory [9] was presented to the Eurostat Working Group on Public Health Statistics in November 1997.

The present paper focuses on the availability of recent and future national health surveys in each country and on the coverage of health indicators by these surveys.

The comparability of the survey questions is described in a separate paper.

The present study focuses on 14 health topics considered in the health monitoring programme [10]. These topics can be classified according to the following three categories: 1. Health status (six topics): disease specific morbidity, chronic conditions, self-assessed health, long-term physical disability, activity limitations and height and weight.

2. Lifestyle and health habits (five topics): smoking habits, alcohol consumption, use of drugs/narcotics, physical activities and diet.

3. Medical consumption (three topics): hospitalisations, general practitioner (GP) consultations and use of medicines.

Examples of survey questions for each topic are presented in Table 1.

In addition, developments in the number of health interview surveys and in the topics they cover since the WHO inventory by Evers [5] are described. In a comparison of these two inventories it should be noted that they examine different topics. The Eurostat inventory addresses topics defined by the Health monitoring programme, whereas the WHO inventory focuses on Health for All topics. Yet, there is a considerable overlap: ten of the 14 topics included in the Eurostat inventory are also included in the WHO inventory. Only disease specific morbidity and the three topics on medical consumption are not included in the WHO inventory. In addition, all the 18 countries included in the Eurostat inventory are also included in the WHO inventory.

\section{[TABLE 1]}

\section{METHODS}

In order to generate a comprehensive overview of national health interview surveys Eurostat contacted national statistical institutes, ministries of health and research institutes in the 15 EU member states, Norway, Iceland and Switzerland in August 1996. The institutes were asked to provide questionnaires of national health interview surveys, surveys on impairments, disabilities and handicaps, multi-purpose surveys, standard of living surveys and other surveys with a health-related component that had been conducted since 1994. Information on plans for future surveys was also requested. For each reported survey the 
institutes were requested to forward information on the methodology (e.g. mode of data collection, sample size and non-response) and the questionnaire in the original language(s) and in English (if available).

Table 2 shows that 43 of the 45 institutes contacted replied and that the majority (33) reported health-related surveys. The institutes provided information on 78 surveys. Thirtyfive studies were excluded from the analysis:

- . Nine surveys that were conducted before 1994.

- . Six future surveys for which no questionnaires were available.

- . Eleven surveys that focused on one specific subject, e.g. family planning.

[TABLE 2]

. Nine surveys that addressed only a part of the population such as children, adolescents or prisoners.

The remaining 43 questionnaires were analysed. We first made an overview of the national health surveys in each country. Secondly, for those countries that have at least one national health interview survey we studied the coverage of 14 health topics.

\section{RESULTS}

\subsection{Availability of health surveys}

Appendix A presents an overview of the 43 national surveys. The majority of the countries have at least one regular health interview survey. Four countries, however, do not have specific health interview surveys: Greece, Luxembourg, Iceland and Ireland. The most recent national health survey in Greece was the 'Survey on health and social determinants in Greece', dating from 1978. More recent health surveys cover only part of the country. The 10-yearly Greek population census inquires after long-term disability. In Luxembourg a panel study titled 'Living in Luxembourg' is conducted twice a year and incorporates many themes including health. In Iceland a multi-purpose survey (the 'Omnibus survey') is reported: the 1994 and 1996 surveys include questions on health promotion. The Irish 'Living in Ireland survey' focuses on living conditions. In addition, two national healthrelated surveys are currently in preparation in Ireland. The Department of Health intends to carry out a 'national lifestyle survey' every 2 or 3 years, covering a wide range of lifestyles like nutrition, exercise and alcohol consumption. The Central Statistics Office started a quarterly multi-purpose household survey, the 'Quarterly labour force:social survey' in 1997. This survey incorporates the contents of the existing annual Labour Force Survey, and from 1998 on other social topics like health, leisure, social contacts, housing and work environment will be added on a modular basis. For the 14 countries that have at least one national health interview survey, a description of the surveys is presented in Appendix B. Appendix A shows the methodological aspects of these surveys. The majority of the surveys use a face-to-face interview (26 surveys; 60\%). About one-third of the surveys (13) combine a face-to-face interview with a self-administered and:or a telephone questionnaire. Three surveys collect data entirely by means of telephone interviews, and one survey uses a self-administered questionnaire. Regarding the frequency of the surveys, health interview surveys are carried out annually in three countries (Finland, France, Sweden) and continuously in another three (Germany, The Netherlands, UK). In the other countries health surveys are conducted less often (every 2 years in Belgium, every 4 years in Italy and Norway, every 5 years in Switzerland, every 6 or 7 years in Denmark and every 10 years in Austria). In Spain and Portugal health surveys are carried out irregularly.

With regard to the age groups of the samples that are addressed, 18 surveys (42\%) include people of all ages, 14 surveys (33\%) use a minimum age level, and 11 surveys (25\%) use both minimum and maximum age levels. Non-response rates range from $5 \%$ to $48 \%$. Most rates vary between $10 \%$ and $30 \%$. The Icelandic survey has the smallest number of 
respondents (1050; about $0.4 \%$ of the national population), while the German microcensus has the largest number (400,000; about $0.5 \%$ of the population).

\subsection{Coverage of health topics}

For the 14 countries that have national health interview surveys the coverage of 14 health topics was studied. We examined whether the main national survey (A1 in Austria, B1 in Belgium, etc.) included these topics, and if not, whether another survey covered these. Table 3 gives an overview of the topics that are measured in each country.

The bottom row in Table 3 shows the number of topics that are measured by national health interview surveys in each country. All countries have national survey data on the majority of the 14 health topics. The fewest number of topics is measured in Austria (ten topics). The surveys in Finland, the UK and Switzerland cover all topics.

The penultimate column in Table 3 indicates for each topic the number of countries that measure it. Seven topics are surveyed in all countries: namely, self-assessed health, longterm physical disability, height and weight, smoking habits, alcohol consumption, physical activity and consultations with the GP. The last column demonstrates how many of the 43 surveys analysed include these topics.

Self-assessed health is included most often (32 surveys), followed by smoking habits (31) and long-term physical disability (28). Questions on the use of drugs:narcotics and on diet are included least often in national health surveys: these topics are measured in eight and nine countries (nine and 11 surveys) respectively.

Table 3 also shows which topics are included in the main national surveys, and which topics are included in other surveys. In Austria, for example, the Microcensus on health provides data on seven topics. The Austrian survey on the consumption of alcohol and psychoactive substances supplements the Microcensus data, as it provides data on alcohol consumption, use of drugs and:or narcotics and physical activities. Generally, topics on health status and medical consumption are predominantly covered by the main national health interview surveys, while topics on lifestyles and health habits are often included in other surveys.

\section{[TABLE 3]}

\section{DISCUSSION}

This discussion addresses four issues in turn: first, the completeness of the present inventory, and then the availability of national health interview surveys since the WHO inventory [5]. Thirdly, developments in the coverage of health topics will be clarified. Finally, the value of national health interview surveys for research and policy purposes will be described.

Does the present inventory give a complete picture of the national health surveys in each country? The employees of the national statistical institutes, ministries of health and research institutes, who collaborated, have an overall view of the health surveys in their country. Nearly all employees whom we contacted replied (96\%). In addition, when they referred to surveys that were conducted by other institutes, these surveys were also included in the inventory. Moreover, the present inventory covered all health surveys that were collected by Evers [5] and by the Centers for Disease Control and Prevention of the US Department of Health and Human Services [11]. Finally, the completeness of the inventory was also discussed with members of the Task Force on Health and Health-related Survey Data and with members of the Working Group on Public Health Statistics. Therefore, we conclude that the present inventory is exhaustive.

In order to examine the development of the availability of national health interview surveys, the results of the present inventory on surveys in the period 1994-2000 were 
compared with those of the WHO inventory on surveys that were conducted between 1980 and 1990. The comparison shows that the number of national health interview surveys in the 18 countries that were examined has increased. Since 1990 regular national health interview surveys have been introduced in Belgium, Germany and Switzerland. As a result, the number of topics covered by surveys in these countries has increased. Whereas in the WHO inventory Belgian and German surveys included only a few health topics, the present inventory shows that these countries nowadays measure nearly all topics.

National health interview surveys were initiated in France, Finland and Norway in the 1960s, in the UK, Austria and Sweden in the 1970s, and in Italy, The Netherlands, Denmark, Spain and Portugal in the 1980s. Generally, both inventories reported the same surveys for most countries. In Spain, Finland, France and the UK the number of regular surveys has increased in the 1990s. In addition to the existing health surveys the Spanish Household survey on drug use, the Finnish FinRisk, the French health barometer, the health survey for England, the Scottish health survey and the English health education monitoring survey have been initiated. The present inventory shows that even more health-related surveys will be initiated in the near future. To give some examples: in Finland preparations are being made for a study on the health of the Finns in the year 2000 (Terveys 2000) and in Ireland a national lifestyle survey that covers health-related questions will be initiated in 1998. Thus, the number of national health interview surveys is rising.

To have a complete overview of the availability of health surveys in a particular year, the frequency of the surveys should be taken into account. In six countries health interview surveys are conducted annually or continuously. In the other countries health surveys are carried out less often (varying from 2-yearly to 10-yearly surveys) or irregularly. Thus, in order to have comparable health data, not only the contents of the questionnaires but also the periodicity of the surveys should be attuned.

The comparability of the survey data also depends on the correspondence of the methodological aspects between the surveys. Differences in health outcomes between surveys may be induced by differences in sample frames, data collection methods and:or non-response figures. With regard to the latter, the larger the non-response, the larger the possibility that the respondents represent a particular selection of the original sample. For example, if healthy individuals are more willing to cooperate than unhealthy persons, unhealthy individuals will be underrepresented in the sample. Therefore, methodological differences should be taken into account when the results of different surveys are compared—e.g. by weighting the results according to sex, age and:or other background variables.

The results on the coverage of health topics of the present inventory are in line with the findings of the WHO inventory [5]. Both inventories show that indicators related to health status are included most often, followed by indicators on healthy lifestyles (indicators related to medical consumption were not included in the WHO inventory). Self-assessed health status, smoking habits, long-term disability, activities of daily living, long-term incapacity for work and the consumption of alcohol are covered most often in both inventories. Questions on diet and drugs are included least often in health interview surveys. These two topics require extensive questionnaires, and therefore they are more often included in special surveys.

In conclusion, as most countries have national health interview surveys that provide data on most of the examined topics, national health interview surveys are an important source of information on the health status, lifestyles and medical consumption in these countries. The abundance of national health interview survey data makes these data valuable for studying the diversity in health of Europeans, which may advance the understanding of the determinants of health and disease.

These surveys can also be used to study the effects of different health policy measures in these countries. 
Yet, the value of these survey data for international comparisons depends on the comparability of the survey questions, frequency and methodology of the surveys (like type of survey, sample frame and interview method). Therefore, the WHO, the OECD and the European Commission (Eurostat) advance the comparability of survey data by promoting common methods and instruments. These harmonisation efforts are a prerequisite to increase the comparability. Given the large number of national health interview surveys, harmonisation may be a long, but also a promising endeavour.

\section{ACKNOWLEDGEMENTS}

The authors are grateful to J. Bonte and M. De Smedt of Eurostat for their suggestions and comments. The authors also thank the members of the Task Force on Health and Healthrelated Survey Data and the colleagues of the 43 institutes who cooperated for their helpful contributions.

\section{Appendix A. Overview of national health surveys in Europe}

\section{[TABLE A1]}

\section{Appendix B. Description of national health interview surveys in 14 European}

\section{countries}

The Central Statistical Office in Austria has performed a Microcensus since 1967. This multi-purpose survey is conducted continuously and it includes all kinds of social statistics. The questionnaire includes a compulsory core part and a supplementary voluntary part. The topic of the latter part varies and it includes questionnaires on health (Fragen zur Gesundheit), physical disabilities (Personen mit ko" rperlichen Beeintra"chtigungen) and smoking (Rauchgewohnheiten) [12].

In addition, two Austrian research institutes (Ludwig Boltzmann-Institut für Suchtforschung and Institut fu“" r Markt- und Sozialanalysen) conducted a survey on the consumption of alcohol and psychoactive substances ('Konsum von Alkohol und psychoaktiven Stoffen') in 1993:94. For this survey nationwide quota samples were used, consisting of about 1000 abstainers and moderate drinkers and about 1000 heavy alcohol consumers [13].

In Belgium a national health interview survey (Enque^te de sante') was conducted in 1997. This survey addresses a variety of health-related domains: general health perception, morbidity and functional status, use of health services, lifestyle and socio-economic characteristics. As far as possible, questions were developed according to the recommendations of the WHO. If no recommendations were available, questions that were used in foreign national health surveys or in other Belgian surveys were adopted. As a result, only a few questions have been newly developed.

This survey was conducted in three languages: Dutch (Flemish), French (Walloon) and German. In order to monitor trends it is intended to repeat this survey every 2 years $[14,15]$. The main national health interview survey in Germany is the continuous 'Bundes Gesundheitssurvey' that started in 1997. This survey is based on two former health surveys: the national German Cardiovascular Prevention study performed in West Germany between 1984 and 1991 [16], and a comparable health survey that was carried out in former East Germany in 1991:1992.

As in Austria, the National Statistical Institute conducts a Microcensus continuously. This census regularly covers a health interview survey (Fragen zur Gesundheit): until 1995 every 3 years, and from 1995 onwards every 4 years. The 1999 health questionnaire will probably cover more areas than before [17].

In addition, two German research institutes (Epidemiologische Forschung Berlin and Infratest) carried out a survey on prevention and health promotion (Umwelt, Gesundheit und 
Hupkens, C.L.H., Berg, J. van den, Zee, J. van der. National health interview surveys in Europe: an overview. Health Policy: 1999, 47(2), p. 145-168

Gesundheitsversorgung) in 1995 [18]. Finally, the Federal Institute for Population Research (Bundesinstitut fu" r Bevo"lkerungsforschung) has prepared a health survey that would be conducted in 1997:1998 titled 'Living situation, environment and health'.

The Danish Institute for Clinical Epidemiology conducts a health interview survey every 6 or 7 years to obtain comparable time series of health indicators. So far this survey was conducted in 1987 and 1994. It gives a broad picture of the distribution of health and morbidity in the adult population, like health status, morbidity, health behaviour, health risks and resources and consequences of disease [19].

In Spain a national health survey is conducted irregularly by the Ministry of Health. The most recent survey dates from 1995 [20]. In that year the Ministry of Health and a governmental committee started a 2-yearly household survey on drug use [21]. This survey inquires after health, lifestyles and the use of psychoactive substances, like tobacco, alcohol, medicines and drugs. Respondents who report to use drugs are asked to complete a selfadministered questionnaire. Finally, the National Statistical Institute performed a survey on impairments, disabilities and handicaps in 1986. A new survey is being planned for 1999, provided that this plan is not affected by budgetary restrictions.

In Finland four national institutes carry out a large number of health-related surveys, often in close collaboration: Statistics Finland, the Social Insurance Institution (abbreviated KELA in Finnish), the National Public Health Institute (KTL) and the National Research and Development Centre for Welfare and Health (STAKES). The major nationally representative health interview survey in Finland is the 'Interview survey on health care'. This survey was initiated by the Social Insurance Institution with the introduction of sickness insurance in 1964. Currently, this survey is organised jointly by the four institutes mentioned above and is co-ordinated by KELA and STAKES.

Since the early 1970s the National Public Health Institute has conducted an annual postal survey on health behaviour. Its main emphasis is on cardiovascular disease and health behaviour, but it also collects data on chronic diseases and health care use. The National Public Health Institute also carries out a risk factor survey, which is repeated every 5 years. This survey started in 1972, and it has been part of the WHO-Monica project (FinMonica). Since 1992 it has been named the FinRisk survey. The basic programme contains risk factor and health behaviour components and a dietary survey. A complementary study among the elderly (aged 65-74 years) combines health interview and health examination methods to examine chronic conditions, functional limitations and disabilities. Currently, the National Public Health Institute is planning a new health survey for the year 2000: Health 2000. Like the FinRisk study (which is a pilot project for Health 2000), this survey also combines a health interview survey with a health examination study.

Statistics Finland has been carrying out household surveys on living conditions at irregular intervals since the 1970s. This survey includes a modest part dealing with health, disability and health care utilisation.

In co-operation with Statistics Finland, STAKES conducted a nationwide survey on health services based on computer-assisted telephone interviews in 1994.

STAKES also performs an eight-yearly study on Finnish drinking habits.

In France there are three health interview surveys that are conducted regularly: the decennial health and medical care survey (Enque^te sur la sante' et les soins me'dicaux), the annual survey on health care and social insurance (Enque`te sur la sante' et la protection sociale mise a ' jour) and the 3-yearly health barometer (Barome 'tre sante' grand public). The health and medical care survey (also named the French health survey) has been implemented by the Institut National de la Statistique et des Etudes Economiques (INSEE) and the Centre de Recherche, d'Etude et de Documentation en Economie de la Sante' (CREDES) since 1960 [22,23]. In addition, CREDES has conducted the survey on health care and social insurance since 1988 in order to examine the structure and evolution of medical consumption [24]. 
The health barometer is administered by the Comite' Franc,ais d'Education pour la Sante' (CFES). This survey inquires after opinions, attitudes and health behaviour, including smoking and drinking habits, accidents, medication, vaccinations and sexually transmitted diseases [25].

INSEE is also responsible for a survey on living conditions (Etude sur les conditions de vie). This survey especially focuses on people in deprived situations: disadvantaged areas are overrepresented in the sample. The Centre de Recherche pour l'Etude et l'Observation des Conditions de Vie (CREDOC) conducts an annual survey on living conditions and aspirations of the French (Enquête conditions de vie et aspirations des Franc, ais). This survey also incorporates a few questions on health.

As reliable statistics relating to disabilities of the general French population is lacking, INSEE initiated the French national survey of handicaps, disabilities and dependency (Handicaps, incapacite's, de'pendance). This survey aims to determine the number of handicapped and dependant persons in France, to estimate transition rates in and out of disability, to describe the nature, quantity and current providers of aid, and to estimate the extent of unmet service needs. The survey will be carried out in three phases between 1997 and 1999 [26].

The National Statistical Institute in Italy conducts a yearly multi-purpose household survey. This survey covers a questionnaire on aspects of daily life each year and a questionnaire on health conditions and recourse to health services every 4 years. Data are collected by means of oral interviews and self-administered questionnaires [27].

The National Statistical Institute in The Netherlands (Statistics Netherlands) started a 3yearly standard of living survey in 1974. Since 1989 this survey has been conducted continuously, including, for example, housing conditions, environmental issues, job satisfaction and health and health-related life styles [28]. In order to follow the developments in health, life styles and medical consumption of the Dutch population, Statistics Netherlands initiated a continuous health interview survey in 1981 [29]. Since 1997 both surveys have been integrated into the Permanent survey of living conditions (Permanent onderzoek leefsituatie, POLS). One of the advantages of this survey is that it allows one to study relations between health and aspects of living conditions.

The Portuguese Ministry of Health is responsible for the national health survey.

This survey has been conducted irregularly since 1987. The most recent survey dates from 1995:96, when about 50,000 persons from 17,400 households were interviewed.

The National Statistical Institute (INE) performs a survey on disabilities and handicaps. This survey is also carried out at irregular intervals, most recently in 1994.

Since 1975 Statistics Sweden has carried out the yearly survey of living conditions. This multi-purpose survey includes health-related questions, like the occurrence of illnesses and health behaviour. The surveys conducted in 1988 and in 1996 included more questions on health than surveys in other years. Data are collected primarily through face-to-face interviews. Moreover, as personal interviews and interviews by phone appeared to yield comparable kinds of responses, about $15 \%$ of the respondents are questioned by telephone [30].

In the UK a large number of health-related surveys are performed. Appendix A includes the most relevant surveys. The University of Cambridge School of Clinical Medicine initiated the health and lifestyle survey in 1984:85 in order to examine how people's behaviour and the circumstances in which they live affect their physical and mental health. The random sample included more than 9000 adults living in England, Scotland and Wales. Respondents were re-surveyed in 1991, and if sufficient funds are obtained, a further survey will be carried out in 1998:99 [31].

Commissioned by the Department of Health, the Joint Health Surveys Unit of Social and Community Planning Research (SCPR) and the Department of Epidemiology and Public Health of the University College London (UCL) carry out the yearly health survey for England [32] and the 3-yearly Scottish health survey. 
Hupkens, C.L.H., Berg, J. van den, Zee, J. van der. National health interview surveys in Europe: an overview. Health Policy: 1999, 47(2), p. 145-168

The Office for National Statistics (ONS) has conducted the continuous general household survey since 1971. This survey aims to gain insight into the main variables with which social policy is concerned and in particular into changes over time. On behalf of the Health Education Authority the ONS conducts the health education monitoring survey, which monitors trends in health-related knowledge, attitudes and behaviour of adults in England. To examine the association between intentions expressed in the initial interview in 1995 and subsequent changes in behaviour, follow-up interviews were conducted in 1996, 1997 and 1998 [33]. The ONS also performs the Disability survey. This survey is a follow-up of the family resources survey, and it is conducted irregularly on behalf of the Department of Health. The survey of psychiatric morbidity is also carried out on behalf of the Department of Health.

Statistics Norway conducts a health interview survey every 10 years, most recently in 1995. From 1998 onwards this survey will be part of the 4-yearly standard of living survey.

The Federal Office of Statistics in Switzerland carries out a national health survey (Schweizerische Gesundheitsbefragung) every 5 years. The most recent survey was conducted in 1997 and about 12,500 non-institutionalised persons participated. A complementary survey will probably be conducted in homes for elderly, nursing homes and prisons.

\section{REFERENCES}

[1] WHO:CBS. Health Interview Surveys. Towards International Harmonization of Methods and Instruments. In: European Series, vol. No. 58. Copenhagen: WHO Regional Publications, 1996.

[2] Council of the European Communities, Commission of the European Communities. Treaty on European Union. Luxembourg: Office for Official Publications of the European Communities, 1992.

[3] European Union. Amsterdam Treaty. Luxembourg: Office for Official Publications of the European Communities, 1997.

[4] Commission of the European Communities. Decision No 1400:97:EC of the European Parliament and of the Council of 30 June 1997 adopting a programme of Community action on health monitoring within the frame work for action in the field of public health (1997 to 2001). Off J Eur Commun 1997;40(L 193):1-10.

[5] Evers SMAA. Health for All indicators in health interview surveys. Health Policy 1993; 23: 205-18.

[6] Ericsson A. The importance of lifestyle to self-assessed health. Health Policy 1997; 42: 145-55.

[7] Lund M. European health information today. Eurohealth 1997;4:14-6.

[8] McKee M. An agenda for public health research in Europe. Eur J Public Health 1998;8:37.

[9] Hupkens C.L.H. Coverage of health topics by surveys in the European Union. Eurostat Working Papers Doc OS:E3:97:HIS:2 Rev.1. Luxembourg: Commission Europe'enne, 1997.

[10] Commission of the European Communities. Non-exhaustive list of areas in which health indicators may be established (community action on health monitoring). Off $\mathrm{J}$ Eur Commun 1996;C220: 42-3.

[11] US Department of Health and Human Services. International health data reference guide 1997. Hyattsville: DHHS Publication No. (PHS) 98-1007, 1998.

[12] Austrian Central Statistical Office. The Austrian Microcensus in the International Context. Department on Social Statistics, 1996.

[13] Uhl A, Springer A. Studie über den Konsum von Alkohol und psychoaktiven Stoffen in Österreich unter Berücksichtigung problematischer Gebrauchsmuster. Repräsentativerhebung 1993: 94. Wien: Bundesministerium für Gesundheit und Konsumentenschutz, 1996. 
Hupkens, C.L.H., Berg, J. van den, Zee, J. van der. National health interview surveys in Europe: an overview. Health Policy: 1999, 47(2), p. 145-168

[14] Tafforeau J, Van Oyen H, Reginster G, Schiettecatte E. Vers une enquête de santé par interview en Belgique. Rapport du pré test. IHE: EPISERIE No. 7. Institut d'Hygiène et d'Epidémiologie, Université de Liège, Institut National de Statistique, 1996.

[15] Van Oyen H, Tafforeau J, Hermans H, Quataert P, Schiettecatte E, Lebrun L, Bellamammer L. The Belgian health interview survey. Arch Public Health 1997;55:1-13.

[16] Hoffmeister H, Mensink GBM, Stolzenberg H, Hoeltz J, Kreuter H, Laaser U, Nu“ ssel E, Hülleman KD, von Troschke J. Reduction of coronary heart disease risk factors in the German Cardiovascular Prevention Study. Prev Med 1996;25:135-45.

[17] Hein B. Fragen zur Gesundheit. Ergebnis des Mikrozensus 1995. St BA Wirtsch Stat 1996;10:624- 32.

[18] Kirschner W, Elkeles T. Präventionsanalyse. Gesundheitsrisiken, Gesundheitsverhalten und Inanspruchnahme präventiver Maßnahmen der Bevölkerung Sachsen-Anhalts im Jahr 1995.

Magdeburg: Ministerium für Arbeit, Soziales und Gesundheit des Landes Sachsen-Anhalt, 1996.

[19] Kjøller M, Rasmussen NK, Keiding L, Petersen HC, Nielsen GA. Sundhed og sygelighed i Danmark 1994-og udviklingen siden 1987. København: DIKE, 1995.

[20] Ministerio de Sanidad y Consumo. Encuesta Nacional de Salud de Espanã 1995. Madrid: Ministerio de Sanidad y Consumo, 1996.

[21] Ministerio de Justicia e Interior, Delegación del Gobierno para el Plan Nacional sobre Drogas. Encuesta sobre drogas a la población escolar 1994. Madrid: Ministerio de Justicia e Interior, 1995.

[22] Mormiche P. Enquête sur la santé et les soins médicaux 1991-1992. Présentation de l'enquête. Cour Stat 1990;56.

[23] Sermet C. Enqueête sur la santé et les soins médicaux 1991-1992. Méthodologie. Paris: CREDES Biblio No. 965, 1993.

[24] Bocognano A. Méthode et de'roulement de l'Enête sur la santé et la protection sociale mise à jour. Paris: CREDES Biblio No. 935, 1992.

[25] Baudier F, Dressen C, Grizeau D, Janvrin MP, Warszawski J. Baromotre Santé 19931994, Re'sultats de l'Enquête Périodique sur la Santé des Français. Vanves: Comité Français d'Éducation pour la Santé, 1995.

[26] INSEE. The French National Survey of Handicaps, Disabilities and Dependency: An Outline of the Proposed Study. INSEE, 1995.

[27] Instituto Nazionale di Statistica. Stili di Vita e Condizioni di Salute. Indagini Multiscopo sulle Famiglie. Anni 1993-1994. Roma: Instituto Nazionale di Statistica, 1996.

[28] Netherlands Central Bureau of Statistics. De Leefsituatie van de Nederlandse Bevolking, 1995. Kerncijfers. Voorburg:Heerlen: Centraal Bureau voor de Statistiek, 1996.

[29] Netherlands Central Bureau of Statistics. Netherlands Health Interview Survey 19811991. The Hague: SDU Publishers, 1992.

[30] Statistics Sweden. The Swedish Survey of Living Conditions. Design and Methods. Statistics Sweden, 1996.

[31] The Health Promotion Research Trust. The Health and Lifestyle Survey: Seven Years On. A Review. Cambridge: The Health Promotion Research Trust, 1994.

[32] Joint Health Surveys Unit. Health Survey for England 1994. Summary of Key Findings. London: HMSO, 1996.

[33] Hansbro J, Bridgwood A, Morgan A, Hickman M. Health in England 1996. What People Know, What People Think, What People Do. Summary of Key Findings. London: Stationery Office, 1997. 
Hupkens, C.L.H., Berg, J. van den, Zee, J. van der. National health interview surveys in Europe: an overview. Health Policy: 1999, 47(2), p. 145-168

\section{TABLES}

Table 1

Examples of survey questions regarding 14 health topics

\begin{tabular}{|c|c|}
\hline Health topics & Examples of survey questions \\
\hline \multicolumn{2}{|l|}{ Health status } \\
\hline $\begin{array}{l}\text { Disease specific } \\
\text { morbidity }\end{array}$ & $\begin{array}{l}\text { I am going to read for you a list of conditions/diseases. Please tell me for every } \\
\text { disease/condition whether you suffer from it }\end{array}$ \\
\hline $\begin{array}{l}\text { Chronic condi- } \\
\text { tions }\end{array}$ & Do you have any long-standing illness, disability or infirmity? \\
\hline $\begin{array}{l}\text { Self-assessed } \\
\text { health }\end{array}$ & How is your health in general? \\
\hline $\begin{array}{l}\text { Long-term } \\
\text { physical dis- } \\
\text { ability }\end{array}$ & Can you wash your hands and face on your own? \\
\hline $\begin{array}{l}\text { Activity limita- } \\
\text { tions }\end{array}$ & $\begin{array}{l}\text { Think about the } 2 \text { weeks ending yesterday. Have you cut down on any of the } \\
\text { things you usually do about the house, at work or in your free time because of } \\
\text { illness or injury? }\end{array}$ \\
\hline $\begin{array}{l}\text { Height and } \\
\text { weight }\end{array}$ & $\begin{array}{l}\text { What is your height without shoes? How much do you weigh without clothes } \\
\text { and shoes? }\end{array}$ \\
\hline \multicolumn{2}{|l|}{$\begin{array}{l}\text { Lifestyle and } \\
\text { health habits }\end{array}$} \\
\hline Smoking habits & $\begin{array}{l}\text { Do you smoke? How many cigarettes do you usually smoke on average each } \\
\text { day? }\end{array}$ \\
\hline $\begin{array}{l}\text { Alcohol con- } \\
\text { sumption }\end{array}$ & $\begin{array}{l}\text { During the past week on how many days did you drink alcohol, such as wine, } \\
\text { spirits and beer? }\end{array}$ \\
\hline $\begin{array}{l}\text { Use of drugs/ } \\
\text { narcotics }\end{array}$ & $\begin{array}{l}\text { Have you ever taken cannabis (marijuana, dope, pot, etc.) even it was a long } \\
\text { time ago? }\end{array}$ \\
\hline $\begin{array}{l}\text { Physical activi- } \\
\text { ties }\end{array}$ & What describes best your leisure time activities during the last year? \\
\hline Diet & How often do you eat any fruit, vegetables or salad? \\
\hline \multicolumn{2}{|l|}{$\begin{array}{l}\text { Medical con- } \\
\text { sumption }\end{array}$} \\
\hline Hospitalisations & Have you been admitted to a hospital or clinic during the past 12 months? \\
\hline $\begin{array}{l}\text { GP consulta- } \\
\text { tions }\end{array}$ & $\begin{array}{l}\text { How often have you consulted your GP during the past } 2 \text { weeks ending yester- } \\
\text { day? }\end{array}$ \\
\hline $\begin{array}{l}\text { Use of } \\
\text { medicines }\end{array}$ & Have you taken any prescribed medicine during the past 14 days? \\
\hline
\end{tabular}


Hupkens, C.L.H., Berg, J. van den, Zee, J. van der. National health interview surveys in Europe: an overview. Health Policy: 1999, 47(2), p. 145-168

Table 2

Response on the inventory of national health interview surveys

\begin{tabular}{|c|c|c|c|c|c|c|}
\hline & \multirow[t]{2}{*}{ Country } & \multicolumn{3}{|c|}{ Number of institutes } & \multicolumn{2}{|c|}{ Number of surveys } \\
\hline & & Contacted & Response & Report surveys ${ }^{a}$ & Received & Analysed \\
\hline A & Austria & 3 & 3 & 2 & 5 & 4 \\
\hline B & Belgium & 2 & 2 & 1 & 1 & 1 \\
\hline D & Germany & 5 & 5 & 4 & 8 & 3 \\
\hline DK & Denmark & 3 & 3 & 1 & 2 & 1 \\
\hline $\mathrm{EL}$ & Greoce & 2 & 1 & 1 & 1 & 1 \\
\hline E & Spain & 2 & 2 & 2 & 5 & 3 \\
\hline FIN & Finland & 3 & 3 & 3 & 13 & 6 \\
\hline $\mathrm{F}$ & France & 4 & 4 & 3 & 13 & 5 \\
\hline IRL & Ireland & 2 & 2 & 2 & 6 & 1 \\
\hline I & Italy & 3 & 2 & 1 & 2 & 2 \\
\hline $\mathrm{L}$ & Luxembourg & 3 & 3 & 2 & 3 & 1 \\
\hline NL & The Netherlands & 1 & 1 & 1 & 2 & 2 \\
\hline $\mathrm{P}$ & Portugal & 2 & 2 & 2 & 2 & 2 \\
\hline S & Sweden & 2 & 2 & 1 & 1 & 1 \\
\hline UK & United Kingdom & 5 & 5 & 4 & 10 & 7 \\
\hline $\mathrm{N}$ & Norway & 1 & 1 & 1 & 2 & 1 \\
\hline IS & Iceland & 1 & 1 & 1 & 1 & 1 \\
\hline \multirow[t]{2}{*}{$\mathrm{CH}$} & Switzerland & 1 & 1 & 1 & 1 & 1 \\
\hline & All & 45 & 43 & 33 & 78 & 43 \\
\hline
\end{tabular}

${ }^{a}$ Number of institutes that reported health and health-related surveys.

- Nine surveys that addressed only a part of the population such as children, adolescents or prisoners.

The remaining 43 questionnaires were analysed. We first made an overview of the national health surveys in each country. Secondly, for those countries that have at least one national health interview survey we studied the coverage of 14 health topics.

Table 3

Coverage of topics by health surveys in 14 countries

\begin{tabular}{|c|c|c|c|c|c|c|c|c|c|c|c|c|c|c|c|c|}
\hline Topics & A & B & D & DK & $\mathrm{E}$ & FIN & $\mathrm{F}$ & I & NL & $\mathrm{P}$ & $\mathrm{s}$ & UK & $\mathrm{N}$ & $\mathrm{CH}$ & Countries & Surveys \\
\hline \multicolumn{17}{|l|}{ Health status } \\
\hline Disease specific morbidity & $\approx a$ & $*$ & * & * & * & FIN $2^{b}$ & $*$ & * & $*$ & * & & $*$ & $*$ & $*$ & 13 & 21 \\
\hline Chronic conditions & & $*$ & & * & $*$ & $*$ & & * & * & * & * & * & $*$ & $*$ & 11 & 20 \\
\hline Self-assessed health & * & $*$ & $*$ & s & s & * & * & * & * & $*$ & s & $=$ & * & * & 14 & 32 \\
\hline Long-term physical disability & * & $*$ & * & * & * & * & * & * & * & $*$ & * & * & $*$ & $*$ & 14 & 28 \\
\hline Activity limitations & & * & * & $*$ & $*$ & $*$ & * & * & * & * & $\approx$ & * & $*$ & $*$ & 13 & 25 \\
\hline Height and weight & * & $*$ & D3 & $*$ & $*$ & $*$ & * & * & * & * & * & * & * & * & 14 & 23 \\
\hline \multicolumn{17}{|l|}{ Lifestyle and health habits } \\
\hline Smoking habits & * & $*$ & * & * & * & * & * & $*$ & * & * & * & $*$ & * & * & 14 & 31 \\
\hline Alcohol consumption & A4 & $*$ & * & $*$ & * & * & $*$ & I2 & * & * & * & * & * & $*$ & 14 & 26 \\
\hline Use of drugs/narcotics & A4 & & * & $*$ & E2 & FIN6 & F3 & & & & & UK5 & & $*$ & 8 & 9 \\
\hline Physical activities & A4 & $*$ & * & * & * & * & $*$ & * & NL2 & * & * & * & * & $*$ & 14 & 22 \\
\hline Diet & & $*$ & * & * & & FIN2 & & I2 & & * & & * & * & * & 9 & 11 \\
\hline \multicolumn{17}{|l|}{ Medical consumption } \\
\hline Hospitalisations & & * & * & & * & * & * & * & * & * & * & * & * & $*$ & 12 & 25 \\
\hline GP consultations & * & $*$ & * & $*$ & * & FIN2 & $*$ & * & * & * & * & * & $*$ & * & 14 & 25 \\
\hline Use of medicines & * & * & D3 & * & * & 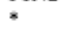 & $*$ & * & s & & * & UK2 & $*$ & $*$ & 13 & 24 \\
\hline Number of topics & 10 & 13 & 13 & 13 & 13 & 14 & 12 & 13 & 12 & 12 & 11 & 14 & 13 & 14 & & \\
\hline
\end{tabular}

a $s$ indicates main national health interview survey: Al, B1, D1, etc.

${ }^{b}$ Topic is not included in the main survey, but in another survey (søe Appendix A for the survey codes). 
Hupkens, C.L.H., Berg, J. van den, Zee, J. van der. National health interview surveys in Europe: an overview. Health Policy: 1999, 47(2), p. 145-168

Table Al

\begin{tabular}{|c|c|c|c|c|c|c|c|c|c|c|}
\hline & Survey & Institute & HIS $^{a}$ & Name & $\begin{array}{l}\text { Frequency, } \\
\text { first year and } \\
\text { following } \\
\text { years }\end{array}$ & $\begin{array}{l}\text { Data } \\
\text { collection }{ }^{\mathrm{b}}\end{array}$ & $\begin{array}{l}\text { Age } \\
\text { (years) }\end{array}$ & $\begin{array}{l}\text { Number of } \\
\text { respondents }\end{array}$ & $\begin{array}{l}\text { Number of } \\
\text { households }\end{array}$ & $\begin{array}{l}\% \text { non- } \\
\text { response }\end{array}$ \\
\hline & $\mathrm{Al}$ & $\begin{array}{l}\text { Österreichisches } \\
\text { Statistisches } \\
\text { Zentralamt } \\
\text { (NSI) }\end{array}$ & * & $\begin{array}{l}\text { Mikrozensus: } \\
\text { Fragen zur } \\
\text { Gesundheit }\end{array}$ & $\begin{array}{l}\text { 10-Yearly } \\
\text { since 1973; } \\
1983 ; 1991\end{array}$ & FF & All & 60,000 & 30,000 & 18 \\
\hline & $\mathrm{A} 2$ & $\begin{array}{l}\text { Österreichisches } \\
\text { Statistisches } \\
\text { Zentralamt } \\
\text { (NSI) }\end{array}$ & & $\begin{array}{l}\text { Mikrozensus: } \\
\text { Personen mit } \\
\text { körperlichen } \\
\text { Beeinträchti- } \\
\text { gungen }\end{array}$ & $\begin{array}{l}\text { 10-Yearly } \\
\text { since 1976; } \\
\text { 1986; } 1995\end{array}$ & FF & All & 60,000 & 30,000 & 7 \\
\hline & $\mathrm{A} 3$ & $\begin{array}{l}\text { Osterreichisches } \\
\text { Statistisches } \\
\text { Zentralamt } \\
\text { (NSI) }\end{array}$ & & $\begin{array}{l}\text { Mikrozensus: } \\
\text { Rauchgewohn- } \\
\text { heiten }\end{array}$ & $\begin{array}{l}\sim 10-\text { Yearly } \\
\text { since 1972; } \\
1979 ; 1986 ; \\
1997\end{array}$ & FF & $16+$ & 60,000 & 30,000 & 5 \\
\hline & A4 & $\begin{array}{l}\text { Ludwig Boltz- } \\
\text { mann-Institut } \\
\text { für Sucht- } \\
\text { forsch. + IMAS }\end{array}$ & & $\begin{array}{l}\text { Konsum von } \\
\text { Alkohol und } \\
\text { psychoaktiven } \\
\text { Stoffen }\end{array}$ & Once: 1993/94 & $\mathrm{FF} / \mathrm{SA}$ & $16+$ & 2015 & - & Quota \\
\hline B & B1 & $\begin{array}{l}\text { IHE Institut } \\
\text { d'Hygiène et } \\
\text { d'Epidémiolo- } \\
\text { gie }\end{array}$ & * & $\begin{array}{l}\text { Enquête de } \\
\text { santé/Gezond- } \\
\text { heidsenquête }\end{array}$ & $\begin{array}{l}\text { 2-Yearly since } \\
1997\end{array}$ & $\mathrm{FF} / \mathrm{SA}$ & All & 10,000 & $\sim 4500$ & $\sim 40$ \\
\hline D & D1 & $\begin{array}{l}\text { RKI Robert } \\
\text { Koch-Institut }\end{array}$ & s & $\begin{array}{l}\text { Bundes } \\
\text { Gesund- } \\
\text { heitssurvey }\end{array}$ & $\begin{array}{l}\text { Continuous } \\
\text { since } 1997\end{array}$ & $\mathrm{FF} / \mathrm{SA}$ & $18-79$ & $\sim 7500$ & - & $\sim 30$ \\
\hline & D2 & $\begin{array}{l}\text { Statistisches } \\
\text { Bundesamt } \\
\text { (NSI) }\end{array}$ & $*$ & $\begin{array}{l}\text { Mikrozensus: } \\
\text { Fragen zur } \\
\text { Gesundheit }\end{array}$ & $\begin{array}{l}\text { Irregular since } \\
1963 ; 3-4 \\
\text { yearly since } \\
1986\end{array}$ & FF & All & 400,000 & - & 10 \\
\hline
\end{tabular}

Table Al (Continued)

\begin{tabular}{|c|c|c|c|c|c|c|c|c|c|c|}
\hline & Survey & Institute & HIS $^{\mathbf{a}}$ & Name & $\begin{array}{l}\text { Frequency, } \\
\text { first year } \\
\text { and following } \\
\text { years }\end{array}$ & $\begin{array}{l}\text { Data } \\
\text { collotion }^{\mathrm{b}}\end{array}$ & $\begin{array}{l}\text { Age } \\
\text { (years) }\end{array}$ & $\begin{array}{l}\text { Number of re } \\
\text { spondents }\end{array}$ & $\begin{array}{l}\text { e-Number of } \\
\text { households }\end{array}$ & $\begin{array}{l}\% \text { non- } \\
\text { response }\end{array}$ \\
\hline & D3 & $\begin{array}{l}\text { EFB Epidemi- } \\
\text { ologische } \\
\text { Forschung } \\
\text { Berlin+Infratest }\end{array}$ & & $\begin{array}{l}\text { Umwelt, } \\
\text { Gesundheit und } \\
\text { Gesundheitsver- } \\
\text { sorgung }\end{array}$ & Once: 1995 & FF & $14+$ & 5000 & - & 32 \\
\hline DK & DKI & $\begin{array}{l}\text { DIKE (Danish } \\
\text { Institute for } \\
\text { clinical Epi- } \\
\text { demiology) }\end{array}$ & * & $\begin{array}{l}\text { Sundhed og } \\
\text { sygelighed } \mathrm{i} \\
\text { Danmark } \\
\text { (Health inter- } \\
\text { view survey in } \\
\text { Denmark) }\end{array}$ & $\begin{array}{l}\text { 6-7-Yearly since } \\
1986 / 87 ; 1994\end{array}$ & $\mathrm{FF} / \mathrm{SA}$ & $16+$ & 4668 & - & 22 \\
\hline $\mathrm{EL}$ & ELl & $\begin{array}{l}\text { National Statis- } \\
\text { tical Service of } \\
\text { Greese (NSI) }\end{array}$ & & $\begin{array}{l}\text { Population } \\
\text { census }\end{array}$ & 10-Yearly; 1991 & FF & All & - & $100 \%$ & - \\
\hline E & $\mathrm{El}$ & $\begin{array}{l}\text { Minsterio de } \\
\text { Sanidad y Con- } \\
\text { sumo (Ministry } \\
\text { of Health) }\end{array}$ & $*$ & $\begin{array}{l}\text { Encuesta na- } \\
\text { cional de salud } \\
\text { (National } \\
\text { health survey) }\end{array}$ & $\begin{array}{l}\text { Irregular since } \\
1987 ; 1993 ; 1995\end{array}$ & FF & All & 8400 & - & - \\
\hline & $\mathrm{E} 2$ & $\begin{array}{l}\text { Ministerio+Delagacion } \\
\text { Plan Nacional Sobre } \\
\text { Drogas }\end{array}$ & & $\begin{array}{l}\text { Encuesta } \\
\text { domiciliaria } \\
\text { sobre uso de } \\
\text { drogas (House- } \\
\text { hold survey on } \\
\text { drug use) }\end{array}$ & $\begin{array}{l}\text { 2-Yearly since } \\
1995\end{array}$ & $\mathrm{FF} / \mathrm{SA}$ & $15+$ & 10,000 & - & - \\
\hline
\end{tabular}


Hupkens, C.L.H., Berg, J. van den, Zee, J. van der. National health interview surveys in Europe: an overview. Health Policy: 1999, 47(2), p. 145-168

Table Al (Continued)

\begin{tabular}{|c|c|c|c|c|c|c|c|c|c|c|}
\hline & Survey & Institute & HIS $^{a}$ & Name & $\begin{array}{l}\text { Frequency, } \\
\text { first year } \\
\text { and following } \\
\text { years }\end{array}$ & $\begin{array}{l}\text { Data } \\
\text { collection }\end{array}$ & $\begin{array}{l}\text { Age } \\
\text { (years) }\end{array}$ & $\begin{array}{l}\text { Number of re- } \\
\text { spondents }\end{array}$ & $\begin{array}{l}\text { Number of } \\
\text { households }\end{array}$ & $\begin{array}{l}\% \text { non- } \\
\text { response }\end{array}$ \\
\hline \multirow{4}{*}{ FIN } & E3 & $\begin{array}{l}\text { INE Instituto } \\
\text { Nacional de Es- } \\
\text { tadistica (NSI) }\end{array}$ & & $\begin{array}{l}\text { Discapidades, } \\
\text { deficiencias y } \\
\text { minusvalias } \\
\text { (Handicaps, } \\
\text { disabilities and } \\
\text { impairments) }\end{array}$ & $\begin{array}{l}\text { Irregular since } \\
\text { 1986; } 1999 \\
\text { (probably) }\end{array}$ & $\mathrm{FF} / \mathrm{SA}$ & All & 270,000 & 75,000 & - \\
\hline & FINI & $\begin{array}{l}\text { STAKES, } \\
\text { KELA, KTL + } \\
\text { Tilastokeskus }\end{array}$ & $*$ & $\begin{array}{l}\text { Terveysden- } \\
\text { huollon väe- } \\
\text { stötutkimus } \\
\text { (Interview sur- } \\
\text { vey on health } \\
\text { care) }\end{array}$ & $\begin{array}{l}\text { Irregular since } \\
1964 ; 1968 ; \\
1976 ; 1987 \\
1995 / 96\end{array}$ & FF & All & - & 4218 & 13 \\
\hline & FIN2 & $\begin{array}{l}\text { KTL } \\
\text { Kansanter- } \\
\text { veyslaitos (Na- } \\
\text { tional Public } \\
\text { Health Insti- } \\
\text { tute) }\end{array}$ & $*$ & $\begin{array}{l}\text { Aikuisväestön } \\
\text { terveyskäyt- } \\
\text { täymistutkimus } \\
\text { (Survey on } \\
\text { health be- } \\
\text { haviour) }\end{array}$ & $\begin{array}{l}\text { Yearly since } \\
\text { early } 1970 \text { s }\end{array}$ & SA & $15-64$ & 3600 & - & 25 \\
\hline & FIN3 & $\begin{array}{l}\text { KTL } \\
\text { Kansanter- } \\
\text { veyslaitos (Na- } \\
\text { tional Public } \\
\text { Health Insti- } \\
\text { tute) }\end{array}$ & * & FinRisk & $\begin{array}{l}\text { 5-Yearly since } \\
1997\end{array}$ & $\mathrm{FF} / \mathrm{SA}$ & $25-74$ & $\sim 12,500$ & - & - \\
\hline \multicolumn{11}{|c|}{ Table Al (Continued) } \\
\hline & Survey & Institute & HIS $^{\mathrm{a}}$ & Name & $\begin{array}{l}\text { Frequency, } \\
\text { first year } \\
\text { and following } \\
\text { years }\end{array}$ & $\begin{array}{l}\text { Data } \\
\text { collextion }\end{array}$ & $\begin{array}{l}\text { Age } \\
\text { (years) }\end{array}$ & $\begin{array}{l}\text { Number of re- } \\
\text { spondents }\end{array}$ & $\begin{array}{l}\text { Number of } \\
\text { households }\end{array}$ & $\begin{array}{l}\% \text { non- } \\
\text { response }\end{array}$ \\
\hline & FIN4 & $\begin{array}{l}\text { Tilastokeskus } \\
\text { (NSI) }\end{array}$ & & $\begin{array}{l}\text { Elinolotutkimus } \\
\text { (Living con- } \\
\text { ditions survey) }\end{array}$ & $\begin{array}{l}\text { Irregular since } \\
\text { early } 1970 \mathrm{~s}\end{array}$ & FF & $15+$ & 23,158 & 8650 & 27 \\
\hline & FIN5 & $\begin{array}{l}\text { STAKES } \\
+ \text { Tilastokeskus }\end{array}$ & & $\begin{array}{l}\text { Aikuisvãestön } \\
\text { terveyspalvelujen } \\
\text { käyttö ja ter- } \\
\text { veydentila } \\
\text { (Survey on } \\
\text { health services) }\end{array}$ & Once: 1993/94 & $\mathrm{T}$ & $25-79$ & 3250 & - & 29 \\
\hline & FIN6 & STAKES & & $\begin{array}{l}\text { Finnish drinking } \\
\text { habits survey }\end{array}$ & 8-Yearly; 1992 & FF & $15-69$ & 3624 & - & 13 \\
\hline \multirow[t]{3}{*}{$\mathrm{F}$} & F1 & $\begin{array}{l}\text { INSEE+ } \\
\text { CREDES }\end{array}$ & * & $\begin{array}{l}\text { Enquête sur la } \\
\text { santé et les soins } \\
\text { médicaux }\end{array}$ & $\begin{array}{l}\text { 10-Yearly since } \\
1960 ; 1970 ; \\
1980 ; 1991 / 92\end{array}$ & FF & All & 21,500 & 8000 & 6 \\
\hline & $\mathrm{F} 2$ & CREDES & $*$ & $\begin{array}{l}\text { Enquête sur la } \\
\text { santé et la pro- } \\
\text { tection sociale } \\
\text { mise à jour }\end{array}$ & $\begin{array}{l}\text { Yearly since } \\
1988\end{array}$ & $\mathrm{FF} / \mathrm{T}$ & All & 9934 & 3386 & 12 \\
\hline & F3 & $\begin{array}{l}\text { CFES Comité } \\
\text { Français } \\
\text { d'Education } \\
\text { pour la Santé }\end{array}$ & $*$ & $\begin{array}{l}\text { Baromètre santé } \\
\text { grand public }\end{array}$ & $\begin{array}{l}\text { 1993/94; } \\
\text { 3-yearly } \\
\text { since } 1995\end{array}$ & $\mathrm{~T}$ & $18-75$ & 1993 & - & 25 \\
\hline
\end{tabular}


Hupkens, C.L.H., Berg, J. van den, Zee, J. van der. National health interview surveys in Europe: an overview. Health Policy: 1999, 47(2), p. 145-168

Table Al (Continued)

\begin{tabular}{|c|c|c|c|c|c|c|c|c|c|c|}
\hline & Survey & Institute & HIS $^{a}$ & Name & $\begin{array}{l}\text { Frequency, } \\
\text { first year } \\
\text { and following } \\
\text { years }\end{array}$ & $\begin{array}{l}\text { Data } \\
\text { collection }\end{array}$ & $\begin{array}{l}\text { Age } \\
\text { (years) }\end{array}$ & $\begin{array}{l}\text { Number of re- } \\
\text { spondents }\end{array}$ & $\begin{array}{l}\text { Number of } \\
\text { households }\end{array}$ & $\begin{array}{l}\% \text { non- } \\
\text { response }\end{array}$ \\
\hline & F4 & INSEE & & $\begin{array}{l}\text { Etude sur les } \\
\text { conditions de } \\
\text { vie (situations } \\
\text { défavorisées) }\end{array}$ & $\begin{array}{l}\text { 8-Yearly since } \\
1978 / 79 \\
1986 / 87 \\
1993 / 94\end{array}$ & FF & $18+$ & 13,280 & 13,280 & - \\
\hline & F5 & CREDOC & & $\begin{array}{l}\text { Enquête condi- } \\
\text { tions de vie et } \\
\text { aspirations des }\end{array}$ & $\begin{array}{l}\text { Yearly; } \\
1994 / 95\end{array}$ & FF & $15+$ & 2005 & - & Quota \\
\hline IRL & IRLI & $\begin{array}{l}\text { Economic and } \\
\text { Social Research } \\
\text { Institute }\end{array}$ & & $\begin{array}{l}\text { Français } \\
\text { Living in Ire- } \\
\text { land survey }\end{array}$ & Yearly; 1996 & FF & All & 9905 & 4048 & 38 \\
\hline \multirow[t]{2}{*}{ I } & Il & $\begin{array}{l}\text { Instituto } \\
\text { Nazionale di } \\
\text { Statistica (NSI) }\end{array}$ & * & $\begin{array}{l}\text { Condizioni di } \\
\text { salute e ricorso } \\
\text { ai servizi sani- } \\
\text { tari (Health } \\
\text { conditions and } \\
\text { services) }\end{array}$ & $\begin{array}{l}\text { 3-4early } \\
\text { since 1980; } \\
1983 ; 1986 ; \\
1990 ; 1994\end{array}$ & FF & All & 60,000 & 20,000 & 10 \\
\hline & I2 & $\begin{array}{l}\text { Instituto } \\
\text { Nazionale di } \\
\text { Statistica (NSI) }\end{array}$ & & $\begin{array}{l}\text { Aspetti della } \\
\text { vita quotidiana } \\
\text { (Aspects of } \\
\text { daily life) }\end{array}$ & Yearly; 1995 & $\mathrm{FF} / \mathrm{SA}$ & All & 60,000 & 20,000 & 10 \\
\hline L & L1 & $\begin{array}{l}\text { CEPS/IN- } \\
\text { STEAD }\end{array}$ & & $\begin{array}{l}\text { Panel socio- } \\
\text { óconomique } \\
\text { Liewen zu } \\
\text { Letzebuerg } \\
\text { (Panel Living } \\
\text { in Luxemboung) }\end{array}$ & $\begin{array}{l}\text { Twice a year } \\
\text { since } 1984\end{array}$ & FF & All & 8192 & 2978 & 48 \\
\hline
\end{tabular}

Table Al (Continued)

\begin{tabular}{|c|c|c|c|c|c|c|c|c|c|c|}
\hline & Survey & Institute & HIS $^{a}$ & Name & $\begin{array}{l}\text { Frequency, } \\
\text { first year } \\
\text { and following } \\
\text { years }\end{array}$ & $\begin{array}{l}\text { Data } \\
\text { collection }\end{array}$ & $\begin{array}{l}\text { Age } \\
\text { (years) }\end{array}$ & $\begin{array}{l}\text { Number of re- } \\
\text { spondents }\end{array}$ & $\begin{array}{l}\text { Number of } \\
\text { households }\end{array}$ & $\begin{array}{l}\% \text { non- } \\
\text { response }\end{array}$ \\
\hline \multirow[t]{2}{*}{ NL } & NL1 & $\begin{array}{l}\text { Centraal Bu- } \\
\text { reau voor de- } \\
\text { Statistiek (NSI) }\end{array}$ & $*$ & $\begin{array}{l}\text { Gezondheid- } \\
\text { senquête } \\
\text { (Health inter- } \\
\text { view survey) }\end{array}$ & $\begin{array}{l}\text { Continuous } \\
\text { since } 1981\end{array}$ & $\mathrm{FF} / \mathrm{SA}$ & All & 9000 & 3500 & 42 \\
\hline & NL2 & $\begin{array}{l}\text { Centraal Bu- } \\
\text { reau voor de } \\
\text { Statistiek (NSI) }\end{array}$ & & $\begin{array}{l}\text { Doorlopend } \\
\text { leefsituatie on- } \\
\text { derzoek (Stan- } \\
\text { dard of living } \\
\text { survey) }\end{array}$ & $\begin{array}{l}\text { 3-Yearly } \\
\text { since 1974; } \\
\text { continuous } \\
\text { since } 1989\end{array}$ & FF & $18+$ & 4000 & 4000 & 46 \\
\hline \multirow[t]{2}{*}{ P } & PI & $\begin{array}{l}\text { Ministério da } \\
\text { Saúde (Ministry } \\
\text { of Health) }\end{array}$ & $*$ & $\begin{array}{l}\text { Inquénito na- } \\
\text { cional de saúde } \\
\text { (National } \\
\text { health survey) }\end{array}$ & $\begin{array}{l}\text { Irregular } \\
\text { since 1987; } \\
1995 / 96\end{array}$ & FF & All & 50,000 & 17,400 & 27 \\
\hline & $\mathrm{P} 2$ & $\begin{array}{l}\text { INE Instituto } \\
\text { Nacional de Es- } \\
\text { tatística (NSI) }\end{array}$ & & $\begin{array}{l}\text { Inquénito na- } \\
\text { cional à defi- } \\
\text { ciênca (Nat- } \\
\text { ional survey } \\
\text { on disabilities) }\end{array}$ & $\begin{array}{l}\text { Irregular, } \\
1994\end{array}$ & FF & All & - & - & - \\
\hline$S$ & S1 & $\begin{array}{l}\text { SCB Statis- } \\
\text { tiska Central- } \\
\text { byrån (NSI) }\end{array}$ & * & $\begin{array}{l}\text { Undersökn- } \\
\text { ingen av levna- } \\
\text { dsförhállanden } \\
\text { (Living condi- } \\
\text { tions survey) }\end{array}$ & $\begin{array}{l}\text { Yearly } \\
\text { since } 1975\end{array}$ & FF & $16-84$ & 5500 & - & 20 \\
\hline
\end{tabular}


Hupkens, C.L.H., Berg, J. van den, Zee, J. van der. National health interview surveys in Europe: an overview. Health Policy: 1999, 47(2), p. 145-168

Table Al (Continued)

\begin{tabular}{|c|c|c|c|c|c|c|c|c|c|c|}
\hline & Survey & Institute & HIS $^{\mathrm{a}}$ & Name & $\begin{array}{l}\text { Frequency, } \\
\text { first year } \\
\text { and following } \\
\text { years }\end{array}$ & $\begin{array}{l}\text { Data } \\
\text { collection }\end{array}$ & $\begin{array}{l}\text { Age } \\
\text { (years) }\end{array}$ & $\begin{array}{l}\text { Number of re- } \\
\text { spondents }\end{array}$ & $\begin{array}{l}\text { Number of } \\
\text { households }\end{array}$ & $\begin{array}{l}\% \text { non- } \\
\text { response }\end{array}$ \\
\hline \multirow[t]{6}{*}{ UK } & UK1 & $\begin{array}{l}\text { SCPR }+ \\
\text { University of } \\
\text { Cambridge } \\
\text { Clinical School }\end{array}$ & $*$ & $\begin{array}{l}\text { Health and } \\
\text { lifestyle survey }\end{array}$ & $\begin{array}{l}\text { 7-Yearly since } \\
\text { 1984/85; 1991; } \\
1998 / 99\end{array}$ & FF & $25+$ & 5352 & 5352 & 14 \\
\hline & UK2 & $\begin{array}{l}\text { SCPR + Uni- } \\
\text { versity College } \\
\text { London }\end{array}$ & $*$ & $\begin{array}{l}\text { Health survey } \\
\text { for England }\end{array}$ & $\begin{array}{l}\text { Continuous } \\
\text { since } 1990\end{array}$ & $\mathrm{FF} / \mathrm{SA}$ & $2+$ & 16,055 & 9084 & 22 \\
\hline & UK3 & $\begin{array}{l}\text { SCPR + } \\
\text { University } \\
\text { College } \\
\text { London }\end{array}$ & $*$ & $\begin{array}{l}\text { Scottish health } \\
\text { survey }\end{array}$ & $\begin{array}{l}\text { 3-Yearly; } \\
1995\end{array}$ & FF & $16-64$ & 7932 & - & 19 \\
\hline & UK4 & $\begin{array}{l}\text { ONS Office } \\
\text { for National } \\
\text { Statistics (NSI) }\end{array}$ & & $\begin{array}{l}\text { General house- } \\
\text { hold survey }\end{array}$ & $\begin{array}{l}\text { Continuous } \\
\text { since } 1971\end{array}$ & FF & $16+$ & 18,000 & 9700 & 15 \\
\hline & UK5 & $\begin{array}{l}\text { ONS Office for } \\
\text { National Statis- } \\
\text { tics (NSI) }\end{array}$ & & $\begin{array}{l}\text { Health oduca- } \\
\text { tion monitor- } \\
\text { ing survey }\end{array}$ & $\begin{array}{l}\text { Yearly since } \\
1995\end{array}$ & FF & $16-74$ & 4700 & - & 24 \\
\hline & UK6 & $\begin{array}{l}\text { Department of } \\
\text { Health + ONS }\end{array}$ & & $\begin{array}{l}\text { Disability } \\
\text { survey (follow- } \\
\text { up of Family } \\
\text { resources survey) }\end{array}$ & $\begin{array}{l}\text { Irregular, } \\
1996 / 97\end{array}$ & FF & $16+$ & $\sim 7000$ & - & - \\
\hline \multicolumn{11}{|c|}{ Table Al (Continued) } \\
\hline & Survey & Institute & HIS $^{a}$ & Name & $\begin{array}{l}\text { Frequency, } \\
\text { first year } \\
\text { and following } \\
\text { years }\end{array}$ & $\begin{array}{l}\text { Data } \\
\text { collection }{ }^{\mathrm{b}}\end{array}$ & $\begin{array}{l}\text { Age } \\
\text { (years) }\end{array}$ & $\begin{array}{l}\text { Number of re- } \\
\text { spondents }\end{array}$ & $\begin{array}{l}\text { Number of } \\
\text { households }\end{array}$ & $\begin{array}{l}\% \text { non- } \\
\text { response }\end{array}$ \\
\hline & UK 7 & $\begin{array}{l}\text { Department of } \\
\text { Health + ONS }\end{array}$ & & $\begin{array}{l}\text { Survey of } \\
\text { psychiatric } \\
\text { morbidity }\end{array}$ & $\begin{array}{l}\text { Irregular; } \\
\text { 1993/94 }\end{array}$ & FF & $16-64$ & 12,500 & - & 20 \\
\hline $\mathrm{N}$ & NI & $\begin{array}{l}\text { Statistik Sen- } \\
\text { tralbyrå (NSI) }\end{array}$ & ${ }^{*}$ & $\begin{array}{l}\text { Helseun- } \\
\text { dersokelsen } \\
\text { (Health inter- } \\
\text { view survey) }\end{array}$ & $\begin{array}{l}1968 ; 1975 ; \\
1985 ; 1995 ; \\
\text { 4yearly since } \\
1998\end{array}$ & FF/SA & All & 10,248 & $\sim 5200$ & 24 \\
\hline IS & ISI & $\begin{array}{l}\text { Social Science } \\
\text { Research Insti- } \\
\text { tute, University } \\
\text { of Iceland }\end{array}$ & & $\begin{array}{l}\text { Pjóömálakönn- } \\
\text { un (Omnibus } \\
\text { survey) }\end{array}$ & Irregular; 1996 & $\mathrm{~T}$ & $18-75$ & 1053 & - & 28 \\
\hline $\mathrm{CH}$ & $\mathrm{CHI}$ & $\begin{array}{l}\text { Bundesamt für } \\
\text { Statistik (NSI) }\end{array}$ & * & $\begin{array}{l}\text { Schweizerische } \\
\text { Gesundheitsbe- } \\
\text { fragung }\end{array}$ & $\begin{array}{l}\text { 5-Yearly; 1992; } \\
1997\end{array}$ & $\mathrm{FF} / \mathrm{T} / \mathrm{SA}$ & $15+$ & $\sim 12,500$ & $\sim 12,500$ & 28 \\
\hline
\end{tabular}

a* Indicates HIS (health interview survey)

${ }^{\mathrm{b}} \mathrm{FF}$, face-to-face; SA, self-administered; T, telephone.

${ }^{\circ}$ National statistical institute. 